\title{
A KÖRFORGÁSOS GAZDASÁG AZ EURÓPAI UNIÓBAN, FRANCIAORSZÁGBAN ÉS NÉMETORSZÁGBAN
}

\section{CIRCULAR ECONOMY IN THE EUROPEAN UNION, FRANCE AND GERMANY}

\author{
Pomázi István', Szabó Elemér ${ }^{2}$ \\ 'Dr. habil., PhD, egyetemi magántanár, Eötvös Loránd Tudományegyetem, Budapest \\ pomazi.istvan@gmail.com \\ ${ }^{2} \mathrm{PhD}$, vezetố-fötanácsos, Agrárminisztérium, Budapest \\ szabelem@gmail.com (levelező szerzó)
}

\begin{abstract}
ÖSSZEFOGLALÁS
A jelenlegi gazdasági modellt a termelés és fogyasztás lineáris megközelítése uralja, amelynek során a különböző nyersanyagokat a természetből kitermelik, majd azokból használati termékeket állítanak elő. A használatot követően jelentős mennyiségű hulladék keletkezik, jelentős része pedig lerakásra kerül. A körforgásos gazdaság fogalma az elmúlt évtizedben egyre népszerúbbé vált, mert mind a döntéshozók, mind az üzleti élet szereplői alternatívákat keresnek a jelenlegi gazdasági modell helyett. A körforgás elvét alkalmazó megközelítés egyik fő célja a gazdasági növekedés szétválasztása az erőforrások felhasználásától, ezáltal az erőforrás-termelékenység javítása. A körforgásos gazdaság felé történő átmenet új gazdasági és foglalkoztatási lehetőségeket teremthet, és hatékonyabb erőforrás-használat révén jelentős környezeti és társadalmi haszonnal járhat együtt. A fejlett országok csoportja, ezen belül is az Európai Unió fontos szerepet játszik a körforgásos gazdaság modelljének kialakításában és megvalósításában. A tanulmány célja az Európai Unió körforgásos gazdasághoz kapcsolódó szakpolitikai törekvéseinek áttekintése és két élenjáró tagállam, Franciaország és Németország erőfeszítéseinek bemutatása.
\end{abstract}

\section{ABSTRACT}

The present economic model is dominated by a linear approach of production and consumption, in the process different raw materials are extracted from nature, and goods are produced for different uses. After using these products huge amount of waste is generated and most of it ends up in landfills. The concept of circular economy has become popular in the last decade: both decision makers and businesses are looking for alternative solutions for replacing the present economic model. The main aim of the circular economy approach is to decouple the economic growth from resource use and improving resource efficiency. The transition to circular economy would generate new economic and employment opportunities, and would be accompanied by significant environmental and social benefits via more efficient use of resources. The group of developed countries, including the European Union, plays an important role 
in the formulation and implementation of the circular economy model. The aim of this study is to review the policy measures of the European Union and the efforts of its two leading member states, France and Germany, in the context of circular economy.

Kulcsszavak: erőforrás-hatékonyság, körforgásos gazdaság, Európai Unió, Franciaország, Németország

Keywords: resource efficiency, circular economy, European Union, France, Germany

\section{EURÓPAI UNIÓ}

A körforgásos gazdaságról szóló csomag, amelyet az Európai Bizottság 2015. december 2-án fogadott el, komoly lendületet adott a körforgásos gazdaságra való átmenetnek az Unióban. A csomag jogalkotási javaslatokat tartalmazott a hulladékok kezeléséről, és a hulladéklerakás csökkentése, valamint az újrafeldolgozás és az újrafelhasználás növelése érdekében hosszú távra szóló célértékeket határozott meg. A zárt láncú termékéletciklus megvalósítása érdekében a csomag emellett egy cselekvési tervet is felvázolt, amelynek célja, hogy az értéklánc minden egyes állomásán támogassa a körforgásos gazdaságot - a termeléstől a fogyasztásig, a javítástól a gyártásig, beleértve a hulladékgazdálkodást és a gazdaságba visszaforgatott másodnyersanyagokat.

Az ezredfordulót követő évtizedben több ország fogott bele erőforrás-hatékonyság növelését célzó szakpolitikák fejlesztésébe. 2005-ben az Európai Bizottság is elóállt a természeti erőforrások fenntartható használatának saját tematikus stratégiájával (European Commission, 2005), amit követett az Eröforrás-hatékony Európa Ütemterve (European Commission, 2011a, b). 2014-ben lépett életbe a Hetedik Környezetvédelmi Cselekvési Program (2014-2020), amelynek célja az Európai Unió elmozdítása az alacsony szénkibocsátású, erőforrás-hatékony gazdaság felé, továbbá az emberi egészség védelme (European Commission, 2014a).

$\mathrm{Az}$ „Európa 2020” stratégia célja, hogy intelligens (tudáson és innováción alapuló), fenntartható (a környezettudatos gazdasági növekedés hosszabb távon fenntarthatóbb lesz) és inkluzív (a foglalkoztatottság magas szintje jobb társadalmi és területi kohéziót eredményez) gazdasági növekedést segítsen elő (European Commission, 2010).

Az Európa 2020 stratégia hét kiemelt kezdeményezése közül az egyik az erőforrás-hatékony Európa megteremtésére irányul (European Commission, 2011c), és hosszú távú cselekvési keretet biztosít a környezetvédelemre és az éghajlatváltozásra, az energiaügyre, a szállításra, az iparra, a mezőgazdaságra, a halászatra és a regionális fejlesztésre vonatkozó politikai menetrendek megvalósításához. A cél 
az, hogy az egyes érintett szakpolitikai területeket összehangolva az erőforrás-hatékonyság érdekében kiszámíthatóbb környezetet biztosítson a beruházások és az innováció számára, és ezáltal megteremtse a fenntartható gazdasági növekedés lehetőségét (1. ábra). Az ábrán és a tanulmány többi ábráján az erőforrás-termelékenység szerepel, ami az egységnyi erőforrás-felhasználásra jutó GDP-termelést jelenti (például GDP/kg), és pontosan reciproka az erőforrás-igényességnek (például kg/GDP), ami viszont az erőforrás-hatékonyság egyik mércéje.

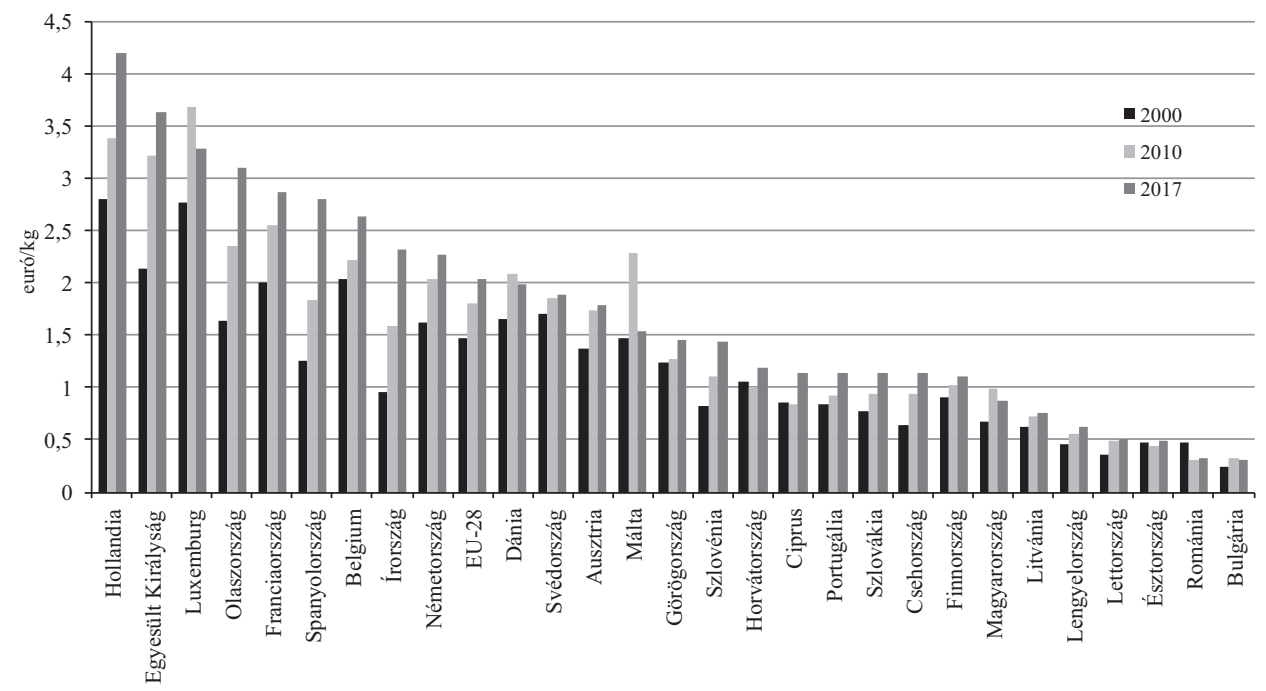

1. ábra. Az EU-tagországok erőforrás-termelékenysége, 2000-2017 (Eurostat) (URL1)

Az Európai Bizottság az erőforrás-hatékony Európa megvalósításának ütemterve útján cselekvési keretet javasolt, és kiemelte, hogy sok szakpolitikai területet és szintet átfogó integrált megközelítésre van szükség. Az ütemterv fö elképzeléseit a Hetedik Környezetvédelmi Cselekvési Program (2014-2020) dolgozta ki részletesebben.

Szlávik János helyesen állapítja meg, hogy a fenntartható fejlődés stratégiája az emberiség hosszú távú programja, és ennyiben globális, a megvalósításnak azonban a globális mellett értelmezhetők a nagyregionális (például Európai Unió), nemzeti és helyi, kisregionális szintjei is (Szlávik, 2013). Ez a megközelítés teljes mértékben érvényes a körforgásos gazdaság megvalósításának földrajzi szintjeire is.

A körforgásos gazdasággal kapcsolatos cselekvési terv középpontjában a magas hozzáadott értékü, uniós szintủ fellépés áll. A körforgásos gazdaság megvalósítása ugyanakkor minden szinten hosszú távú elköteleződést igényel, a tagállamoktól, régióktól és városoktól a vállalkozásokon át a polgárokig. A körforgásos 
gazdaságnak azonban nemcsak európai uniós, hanem globális szinten is meg kell valósulnia. Az EU és az uniós tagállamok által vállalt globális kötelezettségek, így az ENSZ 2030-ig szóló fenntartható fejlődési célkitüzései eléréséhez a körforgásos gazdaságra való áttérés hatékonyan hozzá fog járulni, különösen a 12. célhoz, a fenntartható fogyasztási és termelési minták biztosításához.

Az Európai Bizottság egy közelmúltbeli jelentésében megállapította, hogy az intelligens, fenntartható és inkluzív növekedést célzó Európa 2020 stratégia keretében meghatározott erőforrás-hatékonysági menetrend megvalósulásához elengedhetetlen, hogy elmozdulás történjen a körforgásos gazdaság felé (European Commission, 2014b). A körforgásos gazdaság általánossá tétele érdekében változásoknak kell bekövetkezniük az értékláncok teljes hosszában, a termékek tervezésétől az új üzleti és piaci modellekig, a hulladék erőforrássá alakításának új módozataitól a fogyasztói magatartás új formáiig. Ez a jelenleg múködő gazdasági rendszer teljes megváltoztatását jelenti, valamint innovációt nemcsak a technológiák, hanem a szervezés, a társadalom, a finanszírozási módszerek és a szabályozás terén is.

\section{FRANCIAORSZÁG}

A francia központi kormányzat az elmúlt évtizedekben határozottan ösztönözte az ökotermékek, az ökoinnováció és a körforgásos gazdaság fejlődését azáltal, hogy számos olyan szakpolitikai kezdeményezést és programot hívott életre, amelyek támogatják az ökoinnovációs és K+F-programokat. Ezek a szakpolitikai intézkedések kiegészítik azokat a meglévő támogatási rendszereket, amelyek az innováció egészére irányulnak, és csak részben érintik az ökoinnováció területét.

Regionális szinten a helyi önkormányzatok is támogatják az ökoinnovációt és a körforgásos gazdaságot. Franciaország a közelmúltban többféle kezdeményezést indított a körforgásos gazdaság területén.

A 2010-ben indított Beruházás a jövőért program (Programme d’investissements d'avenir, PIA) egyik fö célja az energia- és ökológiai átmenet támogatása. A PIA egy iparpolitikai eszköz, amely a zöld növekedés katalizátoraként müködik, és bármilyen méretủ innovatív projektet finanszíroz a jövő ipari ágazatainak kialakítása és fejlesztése érdekében. A PIA K+F+I-programokat, infrastruktúrákat és intézményeket finanszíroz, valamint pénzügyi eszközöket (föként tőke és hitelek) biztosít azokhoz az innovatív projektekhez, amelyek különböző ökotechnológiai kérdésekkel foglalkoznak. A PIA 2015-ig összesen 2,85 milliárd eurót különített el az energiatakarékosság és a körforgásos gazdaság kialakítása számára.

Franciaország versenyképességi klaszterek hálózatát hozta létre a köz- és magánszféra kutatási és fejlesztési projektjeinek előmozdítása érdekében az állami kutatás, a vezető kis- és középvállalkozások és a nagyvállalatok közremüködésé- 
vel, különösen az ökoinnovációt célzó termékek a társadalomban és a gazdaságban való elterjesztése céljából. Jelenleg a klaszterek mintegy fele foglalkozik az erőforrások hatékony felhasználásával, valamint a fenntartható város és mobilitás, a megújuló energia és a zöld vegyipar kérdéseivel (European Commission, 2017).

2015 májusában a francia kormány az Új Ipari Franciaország (Nouvelle France Industrielle) elnevezésű programban kilenc kiemelt területet jelölt ki. Ezek közé tartoznak az új erőforrások (az ipari termeléshez szükséges új, biológiai alapú és újrahasznosított anyagok), a fenntartható városok (intelligens hálózatok, épületfelújítás, körforgásos gazdaság), a zöld mobilitás (beleértve az elektromos autókat, a kevesebb mint 2 liter/100 km fogyasztású hagyományos meghajtású autókat, az elektromos töltőállomásokat, a hosszú élettartamú akkumulátorokat) és a jövőbeli szállítási módozatok (gyorsvasutak, ökohajók és hibrid repülőgépek).

A francia parlament 2015-ben fogadta el az Energiaátmenet a zöld növekedésért törvényt (Francia Nemzetgyülés, 2015). Ez a törvény nagyratörő célokat tủzött ki a szén-dioxid-kibocsátás csökkentése, az energiafogyasztás mérséklése, az anyagfelhasználás hatékonyságának javítása, a fosszilis energiafogyasztás visszafogása és a megújuló energia felhasználásának növelése érdekében: például az anyagtermelékenységre vonatkozóan a 2010 és 2030 közötti időszakra 30\%-os növekedést irányzott elö. A törvény a következö ágazatokat célozza meg: ökoépületek, tiszta köz- és magánszállítás, körforgásos gazdaság és megújuló energiák. Ez magában foglalja a szabályozások és az adókedvezmények (például a háztartások energiafelhasználásának javításához kapcsolódó adócsökkentés) kombinációját, továbbá a $\mathrm{K}+\mathrm{F}+\mathrm{I}-$ programok és a célzott, zöld pénzügyi eszközök (például zöld magántőkealapok) támogatását. A törvény részét képezi az az országos, alacsony szén-dioxid-kibocsátású stratégia is, amely meghatározza az üvegházhatású gázok kibocsátáscsökkentésének módját, és amely egyúttal az alacsony szén-dioxid-kibocsátású gazdaság felé történő átmenet megvalósítását is vezérli (European Commission, 2017). A törvény ugyancsak elöírja egy nemzeti körforgásos gazdaság stratégia kidolgozását, amely magában foglalja a természeti erőforrásokra vonatkozó programozási tervet is; ez a stratégia lehetöséget kínál arra, hogy jobban figyelembe vegyék a körforgásos gazdaságra való áttérés erőforrás-hatékonysági potenciálját. A törvény a hulladékok keletkezésének megelőzésére, újrahasznosítására és újrahasználatára, valamint a biomasszaforrásokra vonatkozó nemzeti stratégiára vonatkozó intézkedéseket is elöirányoz (EEA, 2016).

A körforgásos gazdaság területén az innováció fő mozgatórugói az állami $\mathrm{K}+\mathrm{F}+\mathrm{I}-$ programok (például a PIA és versenyképességi klaszterek). Ezek a programok elsősorban a technológiával kapcsolatos kérdésekre összpontosítanak, és kevésbé az innováció egyéb vonatkozásairól (szabályozás, elfogadhatóság, új üzleti modellek stb.) szólnak, habár ezek a területek központi jelentőségünek számítanak a körforgásos gazdaság fejlesztésében. 
A Körforgásos Gazdasági Intézetet (Institut de l'Economie Circulaire, IEC) 2013 februárjában hozták létre azzal a céllal, hogy feltárja azokat az akadályokat és lehetőségeket, amelyek gátolják vagy előmozdítják a körforgásos gazdaság fejlődését. Az intézet az egyik kezdeményezöje a körforgásos gazdaság életre hívásához szükséges jogszabályi változtatásoknak.

Az IEC-vel szoros kapcsolatban áll a francia Környezet- és Energiagazdálkodási Ügynökség (Agence de l'Environnement et de la Maîtrise de l'Énergie, ADEME), amely évek óta aktívan vesz részt a körforgásos gazdaság (ökotervezés, ipari és területi ökológia, fenntartható fogyasztás, hulladékmegelőzés, újrahasznosítás stb.) kialakításában. Az ADEME ezenkívül a környezetvédelem, az energiaügy és a fenntartható fejlödés területén is tevékenykedik. Az ügynökség szakmai hátteret és tanácsadást nyújt a vállalkozásoknak, a helyi önkormányzatoknak és szervezeteknek, az állami szerveknek és a széles társadalom számára, hogy környezetvédelmi tevékenységüket megalapozhassák és megerősíthessék. A munka részeként az ADEME segít a projektek finanszírozásában a kutatástól a végrehajtásig a hulladékgazdálkodás, a talajvédelem, az energiahatékonyság és a megújuló energia, a nyersanyag-megtakarítás, a levegőminőség, a zajcsökkentés, a körforgásos energiaátalakítás és az élelmiszer-hulladék csökkentése területén (ADEME, 2013; ADEME, 2017).

Franciaországnak nincs külön erőforrás-hatékonysági terve vagy stratégiája, de számos kezdeményezést tett, amelyek bizonyos mértékig az erőforrás-hatékonysághoz kapcsolódnak azzal a céllal, hogy ezt a témát valamennyi kapcsolódó szakpolitikába integrálják (2. ábra).

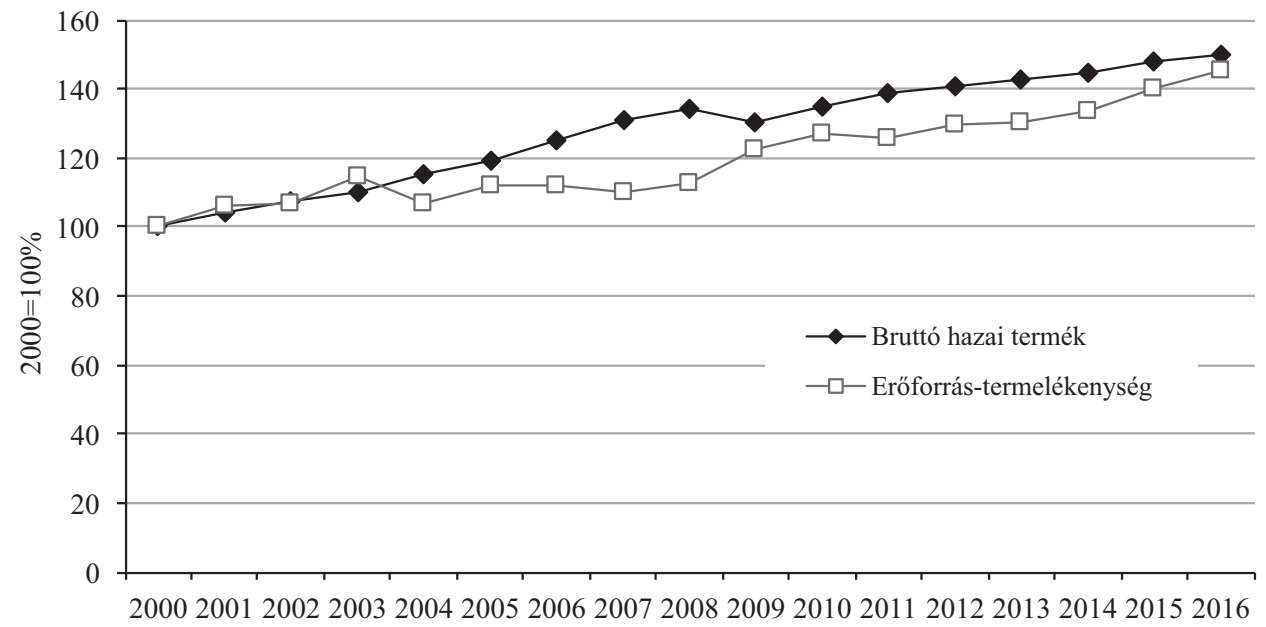

2. ábra. A bruttó hazai termék és az erőforrás-termelékenyég Franciaországban, 2000-2016 (Eurostat) (URL2, URL3) 
A természetierőforrás-felhasználás hatékonyságát számos nemzeti szakpolitika - többek között az éghajlatváltozás, a hulladék, a mezőgazdaság és az erdőgazdálkodás, az építőipar és a közlekedés, a bányászat, a fenntartható fogyasztás és a termelés - ösztönzi. Az anyagfelhasználás hatékonyságára vonatkozó megközelítés nemcsak mennyiségi elemeket tartalmaz, csökkentve a gazdaságban használt anyag összmennyiségét, hanem minőségi szempontból is törekszik az anyagfelhasználás környezeti hatásainak csökkentésére az életciklus mindegyik szakaszában.

Az Ökológiai, Fenntartható Fejlesztési és Energiaügyi Minisztérium (Ministère de l'écologie, du développement durable et de l'énergie, MEDDE) által 2014ben elfogadott, a 2014-2020 közötti időszakra szóló nemzeti hulladékmegelőzési program az erőforrás-hatékonyságot szolgáló törekvések egyike. A program olyan partnerségek kialakítását ösztönzi, amelyek célja az összes érdekeltnek a folyamatba történő bevonása. A program széles eszköztárat kínál fel, hogy minden helyzetben a legmegfelelőbb és leghatékonyabb eszközöket tudják kiválasztani: szabályozási eszközök, önkéntes vállalások, tudatosságnövelés és információcsere, közbeszerzés, valamint támogatások és ösztönzők. A programban végrehajtandó intézkedések a hulladékmegelőzés valamennyi területére kiterjednek, ideértve az ökotervezést és a termékélettartam meghosszabbítását, a termékek újrafelhasználásának, javításának fejlesztését és betétdijjrendszerek létrehozását (MEDDE, 2013).

Az anyaghurkok zárása elsőbbséget élvez, ezért a másodlagos nyersanyagokat nagy fontosságú erőforrásoknak tekintik, lévén azok a helyi ipari üzemek számára erőteljes növekedési lehetőséget biztosítanak, különösen az elemek és akkumulátorok vagy az elektromos és elektronikus berendezések hulladékaiban jelen lévő egyes stratégiai fémek, valamint néhány más anyagforrás, például mủanyaghulladék, csomagolás és bútorok esetében. Franciaországban széles körü kiterjesztett gyártói felelősségi rendszer múködik.

Az újrafeldolgozás azonban csak a körforgásos gazdaság egyik lépcsöjének tekinthető. Az újrafelhasználás, újrahasznosítás, javítás és általánosabban a termék élettartamának meghosszabbítása szintén a körforgásos gazdaság fontos területei, és a hulladékmegelőzési szakpolitikákban prioritásként szerepelnek.

Az Ökológiai Átmenet Nemzeti Tanácsa (Conseil national de la transition écologique, CNTE) foglalkozik a környezetvédelmi vagy energiaügyi kérdésekre vonatkozó javasolt jogszabályokkal, valamint a fenntartható fejlődéssel, a biológiai sokféleséggel és a vállalati társadalmi felelősséggel kapcsolatos nemzeti stratégiákkal, amelyek magukban foglalják a természetierőforrás-hatékonysághoz kapcsolódó témákat is. A tanács tájékoztatást kap a nemzeti fenntartható fejlődési teljesítménymutatók változásairól, amelyek az ökológiai átmenet felé való haladást mérik.

A Stratégiai Fémek Bizottsága (Comité pour les métaux stratégiques, COMES) olyan fórum, amely a stratégiai fémekkel kapcsolatos olyan kérdésekkel foglalko- 
zik, mint például az ellátásbiztonság, az újrafeldolgozás és az integrált irányítás. A COMES-t 2011-ben alapították azzal a céllal, hogy mivel a francia vállalkozások súlyos nehézségekkel szembesülhetnek a nyersfémek beszerzésében; összefogja az érintett vállalkozásokat és hatóságokat, és együttmüködjön más szervekkel nemzeti és európai szinten (COMES, 2017).

A Nemzeti Hulladék Tanács (Conseil national des déchets, CND) munkacsoportjain keresztül vonja be az összes érdekelt felet, beleértve a vállalkozásokat, a fogyasztói szervezeteket, a környezetvédő civil szervezeteket, a hatóságokat, a helyi közösségeket, parlamenti képviselöket, szakértőket és alkalmazottakat.

Az Országos Ipari Tanács (Conseil National de l'Industrie, CNI) integrálta az erőforrás-hatékonyság témáját a munkájába. A tanács munkáját az iparág stratégiai bizottságain keresztül látja el. Egyes stratégiai bizottságok az erőforrás-hatékonyságban közvetlenül részt vevő ágazatokra összpontosítják figyelmüket: az energiahatékonyságra, a megújuló energiaforrásokra, a vízgazdálkodásra és a hulladékhasznosításra (CNI, 2017).

\section{NÉMETORSZÁG}

A német szövetségi kormány 2012. február 29-én fogadta el az első Erőforrás-hatékonysági Programot (rövidítve ProgRess I), amely abból indul ki, hogy az erőforrás-hatékonyság javítása csökkentheti a környezeti terheléseket és károkat, erősítheti a német gazdaság versenyképességét, új munkahelyeket teremthet, és biztosíthatja a hosszú távú foglalkoztatást (BMU, 2012). A program egyik közvetlen előzményeként tekinthető a 2010 októberében elfogadott Nyersanyag-stratégia. 2002-ben a német kormány a Nemzeti Fenntartható Fejlődési Stratégiában azt a célt tűzte ki, hogy 1994-hez képest 2020-ra megkétszerezi a nyersanyag-termelékenységet. A német Erőforrás-hatékonysági Program négy alapelven nyugszik:

1. alapelv: Össze kell kötni az ökológiai szükségszerüségeket a gazdasági lehetőségekkel, az innovációval és a társadalmi felelösséggel.

2. alapelv: A globális felelősségre tekintettel kell lenni a nemzeti erőforrás-politika kidolgozásánál.

3. alapelv: A gazdasági és termelési folyamatokat fokozatosan kevésbé függövé kell tenni az elsődleges erőforrásoktól, fejleszteni kell és kiterjeszteni a zárt ciklusú gazdálkodást.

4. alapelv: A minőségi növekedés megvalósítása érdekében a társadalomnak biztosítania kell a hosszú távú, fenntartható erőforrás-használatot.

A szövetségi Környezetvédelmi Minisztérium (Bundesministerium für Umwelt, Naturschutz und nukleare Sicherheit, BMU) a program elfogadása előtt széles 
körü társadalmi konzultációt folytatott a civil szféra szakértöivel és képviselőivel, a különböző szakmai, tudományos és üzleti szövetségekkel, valamint a tartományokkal.

A program kormányzati elfogadását követően a Bundestag is napirendjére vette a témát, és arra kérte kormányt, hogy négyévente készítsen jelentést a végrehajtásról, értékelje az előrehaladást, és ennek megfelelően fejlessze azt tovább, és végezze el a szükséges módosításokat.

Az átfogó nemzeti program kidolgozásával és elfogadásával Németország elsőként csatlakozott ahhoz az európai uniós törekvéshez, amely az Európa 2020 stratégia keretében célul tüzte ki az Erőforrás-hatékony Európa létrehozását, és egy részletes útitervet dolgozott ki ennek megvalósítására.

2016 márciusában a szövetségi kormány áttekintette a 2012-ben elfogadott program megvalósítását. A bruttó hazai termékre vetített nyersanyag-termelékenység 2014-ben 1994-hez viszonyítva 48,8 százalékkal növekedett, de még jócskán elmarad a 2020-ra kitűzött 100 százalékos céltól (BMU, 2012, 33.). 2015ben a tartományi Gazdasági Miniszterek Konferenciája és a Környezetvédelmi Miniszterek Konferenciája megtárgyalta a ProgRess I végrehajtását, és javaslatokat fogalmazott meg annak felülvizsgálatára és aktualizálására.

Ebbe a folyamatba több kutatóintézet is bekapcsolódott, többek között a 2010ben létrehozott Német Ásványi Nyersanyagok Ügynöksége (Deutschen Rohstoffagentur, DERA), amely rendszeresen elemzi és értékeli a nemzetközi ásványi nyersanyag és fosszilis energia piaci folyamatait.

A ProgRess II kidolgozásakor támaszkodtak a korábban kifejlesztett indikátorokra, de újabb mutató bevezetésére is sor került. A célok egy része továbbra is megmaradt, de újakkal is kiegészült: ilyen például a teljes nyersanyag termelékenység, amelynek a 2000 és 2010 között mért trendjét fenn kívánják tartani 2030-ig.

A ProgRess II meghatározta a 2016-2019 közötti időszak szakpolitikai feladatait is. A 2012-ben elfogadott körforgásos gazdaság törvény (Kreislaufwirtschaftsgesetz, KrWG) meghatározó sarokköve a német erőforrás-politikának. Ez a törvény nagyobb hangsúlyt fektet az erőforrás-takarékoságra, és egy kötelező érvényü keretrendszert határoz meg, amely magába foglalja egy ötszintủ hulladékhierarchia bevezetését és a termékfelelősség elvének erösítését. A törvény kötelezi a kormányt arra is, hogy hulladékmegelőzési programokat dolgozzon ki, és részletes újrahasznosítási arányokat ír elö.

A szövetségi kormány megközelítése szerint az erőforrás-hatékonyság javításának célja a gazdasági prosperitás megőrzése, a környezet védelme és a német ipar versenyképességének erősítése. Az erőforrás-politika kidolgozása és hatékony megvalósítása nem lehetséges az érdekeltek aktív részvétele nélkül. Éppen ezért mindkét erőforrás-hatékonysági program kidolgozása és felülvizsgálata során széles körü konzultációk zajlottak az ipari, környezetvédő és fogyasztóvé- 
delmi szervezetekkel, akadémiai és kutatói közösségekkel, a tartományokkal, az önkormányzatokkal és munkavállalói szövetségekkel.

A szövetségi kormány fontos célnak tekinti az erőforrás-hatékonysági program megvalósításakor a kitermelö- és feldolgozóipar környezetre gyakorolt hatásainak minimalizálását és csökkentését. Mind a ProgRess I, mind a ProgRess II elemzi a teljes értékláncot, kezdve a kitermeléstől és feldolgozástól és a terméktervezéstől a fogyasztáson és az anyagciklusok zárásán keresztül.

A fenti programok végrehajtásakor figyelembe veszik az adminisztratív terhek csökkentését vagy korlátozását, különös figyelemmel a kis- és középvállalkozásokra. Bármilyen intézkedés elfogadása előtt mérlegelik az erőforrás-hatékonyság hasznait és költségeit.

A ProgRess II összesen 123 különböző erőforrás-hatékonysági intézkedést tartalmaz, amelyek nagymértékben hozzájárulhatnak a körforgásos gazdaság felé történő átmenethez (BMU, 2016). A hulladék és a körforgásos gazdaság fókuszban marad, de megjelennek olyan fontos témák is, mint például a fenntartható építkezés és városfejlesztés, valamint az infokommunikációs technológiák és termékek erőforrás-hatékonyságának növelése.

A ProgRess II megvalósításakor új szempont merült fel, amely figyelembe veszi az anyaghatékonyság és az energiahatékonyság közötti kölcsönkapcsolatokat annak érdekében, hogy az ezek közötti integráció és szinergikus hatások erősebbek legyenek.

A ProgRess II továbbfejlesztése megkívánja, hogy további természeti erőforrásokra terjedjen ki a hatóköre, ezért a szövetségi kormánynak feladata a többi stratégiával való konzisztencia megteremtése. Ilyenek például a vízkészletekkel való előrelátó és fenntartható gazdálkodás, beleértve a víztakarékosságot és az újrahasználatot az iparban, mezőgazdaságban és a városfejlesztésben. A levegő is fontos erőforrás, ezért nemcsak a tisztaságának megőrzése a cél, hanem egyes komponenseinek, például az oxigénnek és a nitrogénnek fenntartható hasznosítása.

A talaj szintén nélkülözhetetlen erőforrás az emberi lét, az élelmiszer-biztonság és a biológiai sokféleség számára. A talaj termőképességének hosszú távra szóló fenntartása megköveteli a fenntartható használati módok társadalmilag és környezetileg elfogadható alkalmazását.

Súlyos probléma Németországban is a földterületek gyors ütemű beépítése. A szövetségi Statisztikai Hivatal számításai szerint 2000 és 2013 között az építési és közlekedésfejlesztési célokra kivett földterület nagysága több mint négy és fél ezer négyzetkilométerrel növekedett. Az eröforrás-hatékonyságot célzó intézkedések általában véve hasznosak a biológiai sokféleség megőrzésének szempontjából is.

A BMU 2013 szeptemberében Erőforrás-hatékonysági Nemzeti Platformot (NaRess) állított fel, hogy koordináljon az ipari szövetségekkel. A platform tag- 
ságát 2015-ben környezetvédelmi, fogyasztóvédelmi szervezetek és szakszervezetek képviselöivel bővítették ki. A platform fö feladata az érdekeltek közötti információcsere az erőforrás-hatékonysági tevékenységekről és a ProgRess megvalósításának és továbbfejlesztésének támogatása.

Az erőforrás-hatékonyság előmozdítása érdekében fontos, hogy nagyobb hangsúly helyeződjék a keresleti oldalra és a kínálati oldallal történő összekapcsolásra. A BMU ezért kidolgozta a Nemzeti Fenntartható Fogyasztási Programot, amelyet a kormány 2016 tavaszán fogadott el.

A tartományok fontos szerepet játszanak a természeti erőforrások hatékony felhasználásának elérésében. Már jelenleg is széles körü tevékenységeket folytatnak az iparral, a tudománnyal és a civil társadalommal együttmüködésben. A tartományok intézkedései kiegészítik és támogatják a szövetségi kormány erőfeszítéseit. A tartományok sokkal jobban ismerik a regionális és helyi viszonyokat, és ezzel a tudáshalmazzal tudnak hozzájárulni a szövetségi szintủ intézkedések sikeres megtervezéséhez és megvalósításához.

Az Európai Bizottság 2017 elején részletesen értékelte valamennyi EU-tagállam környezetpolitikájának megvalósítását. Az értékelés szerint Németország a legjobban teljesítő tagállamok közé tartozik a hulladékgazdálkodásban, ahol az újrahasznosítás aránya 2014-ben elérte a 64 százalékot, az energetikai célú égetés a 35 százalékot, és gyakorlatilag megszünt a hulladékok lerakása (European Commission, 2017). Az Eurostat legfrissebb adatai szerint 2015-ben az újrahasznosítási ráta már túllépte a 66 százalékot. Az erőforrás-termelékenység terén vi-

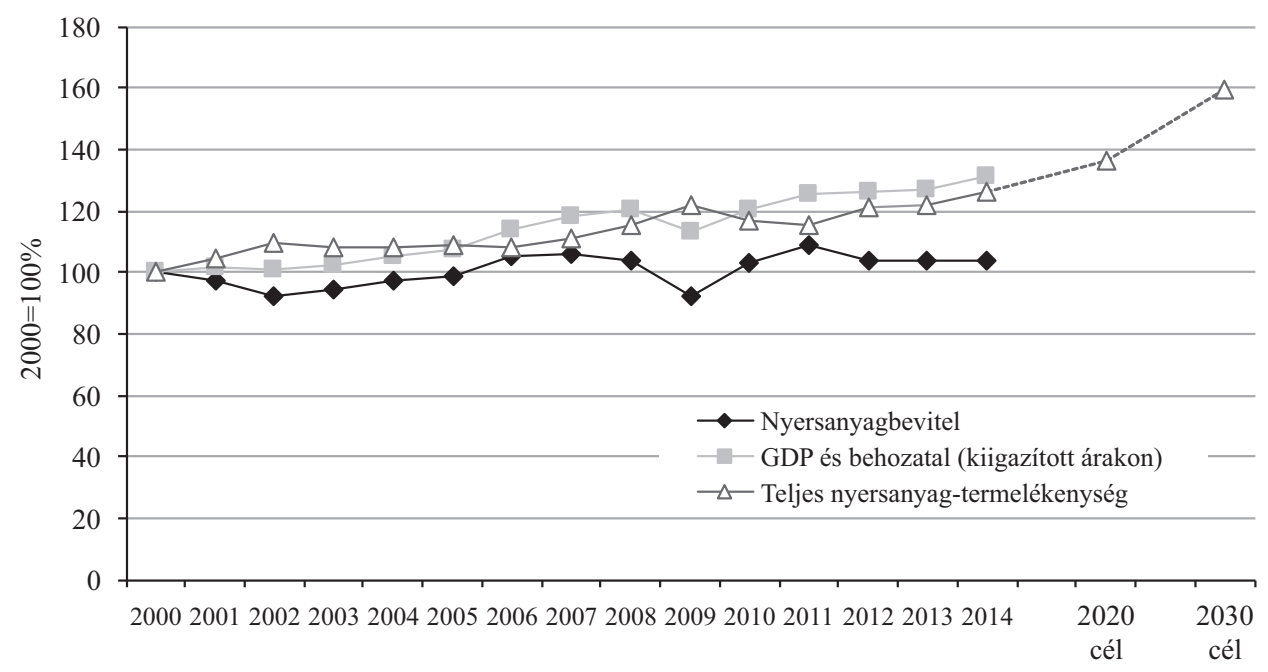

3. ábra. Erőforrás-termelékenység és gazdasági növekedés Németországban, 2000-2030

(UBA) (URL4) 
szont Németország az EU-tagállamok középmezőnyében helyezkedett el $(2,17 \mathrm{~kg}$ szemben a 2,09 kg EU-28 átlaggal). 2003 óta szerény, de stabil növekedés tapasztalható az eröforrás-termelékenységben, illetve nyersanyag-termelékenységben (UBA, 2017) (3. ábra).

\section{ÖSSZEGZÉS}

A tanulmány fö megállapításai a következő pontokban foglalhatók össze:

1. A bemutatott két országra azért esett a választás, mert eleve abba a csoportba tartoznak, amelyek élenjárók a körforgásos gazdaság kialakításának munkálataiban. Ezek az országok már az Európai Unió 2015-ben közzétett körforgásos gazdasági csomagját megelőzően is tettek lépéseket gazdaságuk ilyen irányban történő átalakítása érdekében.

2. A körforgásos gazdaság nem szükíthető le a hulladékgazdálkodás önmagában is összetett kérdéskörére, vagyis a jelenleg elterjedt lineáris gazdasági modellröl a körforgásos gazdaságra való átállás nem pusztán a hulladékok keletkezésének megelőzése és környezetbarát kezelésének problémáit jelenti, hanem a körforgásos gazdaság társadalmi hatásait és emberi viselkedésbeli (fogyasztási) kihívásait is magában foglalja.

3. A fö kihívásokat az jelenti a vizsgált országok esetében, hogyan lehet a körforgásos gazdaságba való átmenet irányítását a lehető leghatékonyabban és megfelelő társadalmi támogatottsággal véghezvinni.

4. Hosszú távon nem kerülhető meg a megosztásos gazdaság, a digitalizáció társadalmi beágyazódásának vizsgálata, az okostelepülések infrastruktúrája, logisztikai szolgáltatásai és a körforgásos gazdaság kölcsönhatásainak részletes feltárása és elemzése.

5. Mindkét EU-tagország esetében érvényes az a megállapítás, hogy a körforgásos gazdasági átmenet sikerének egyik záloga, hogy az összes érdekelt fél - a kormányzat mellett az üzleti szféra, a nem kormányzati szervezetek, valamint a tudományos élet és a felsőoktatás képviselői - részt vesz a folyamatok tervezésében, elfogadásában, megvalósításában és szükség szerinti módosításában.

\section{IRODALOM}

ADEME (2013): Economie circulaire: Notions. Fiche Techniqe. October 2013. http://www.ademe. $\mathrm{fr} / \mathrm{sites} /$ default/files/assets/documents/fiche-technique-economie-circulaire-oct-2014.pdf (Letöltés: 2017. szeptember 10.)

ADEME (2017): http://www.ademe.fr/en/ (Letöltés: 2017. szeptember 10.)

BMU (2012): German Resource Efficiency Programme (ProgRess). Programme for the Sustainable Use and Conservation of Natural Resources. Berlin: BMU, http://www.bmub.bund.de/ fileadmin/Daten_BMU/Pools/Broschueren/progress_broschuere_en_bf.pdf (Letöltés: 2017. augusztus 29.) 
BMU (2016): German Resource Efficiency Programme II. Programme for the Sustainable Use and Conservation of Natural Resources. Berlin: BMU, http://www.bmub.bund.de/fileadmin/ Daten_BMU/Pools/Broschueren/german_resource_efficiency_programme_ii_bf.pdf (Letöltés: 2017. augusztus 29.)

CNI (2017): http://www.entreprises.gouv.fr/conseil-national-industrie/cni/ (Letöltés: 2017. szeptember 5.)

COMES (2017): http://www.mineralinfo.fr/page/comite-metaux-strategiques (Letöltés: 2017. szeptember 5.)

EEA (2016): More from Less-Material Resource Efficiency in Europe. Country Profile: France. http://www.eea.europa.eu/resource-efficiency/ (Letöltés: 2017. szeptember 11.)

European Commission (2005): Thematic Strategy on the Sustainable Use of Natural Resources. (COM (2005) 670 final). Brussels, Belgium: European Commission, https://eur-lex.europa.eu/ legal-content/en/TXT/?uri=CELEX\%3A52005DC0670

European Commission (2010): Europe 2020: A Strategy for Smart, Sustainable and Inclusive Growth (COM/2010/2020 final). Brussels, Belgium: European Commission, https://www.eea. europa.eu/policy-documents/com-2010-2020-europe-2020

European Commission (2011a): Roadmap to a Resource Efficient Europe (COM (2011) $571 \mathrm{fi}$ nal). Brussels, Belgium: European Commission, http://www.europarl.europa.eu/meetdocs/ 2009_2014/documents/com/com_com(2011)0571_/com_com(2011)0571_en.pdf

European Commission (2011b): Commission Staff Working Paper: Analysis Associated with the Roadmap to a Resource Efficient Europe-Part II (COM(2011) 571 final)/(SEC(2011) 1068 final). Brussels, Belgium: European Commission, http://ec.europa.eu/environment/resource_efficiency/pdf/working_paper_part1.pdf

European Commission (2011c): A Resource-efficient Europe-Flagship Initiative under the Europe 2020 Strategy (COM(2011) 21 final). Brussels, Belgium: European Commission, https://www. eea.europa.eu/policy-documents/a-resource-efficient-europe-flagship

European Commission (2014a): General Union Environment Action Programme to 2020 Living Well, within the Limits of Our Planet. Publications Office: Luxembourg, http://ec.europa.eu/ environment/pubs/pdf/factsheets/7eap/en.pdf

European Commission (2014b): Towards a Circular Economy: A Zero Waste Programme for Europe (COM(2014)398 final/2). Brussels, Belgium: European Commission, http://ec.europa. eu/environment/circular-economy/pdf/circular-economy-communication.pdf

European Commission (2015): Closing the Loop - An EU Action Plan for the Circular Economy (COM(2015) 614 final). Brussels, Belgium: European Commission, https://www.eea.europa.eu/ policy-documents/com-2015-0614-final

European Commission (2017): The EU Environmental Implementation Review Country ReportFrance (SWD(2017) 44 final). Brussels, Belgium: European Commission, http://ec.europa.eu/ environment/eir/pdf/full_report_en.pdf

Francia Nemzetgyülés (2015): Loi $2015-992$ du 17 août 2015 relative à la transition énergétique pour la croissance verte. https://www.legifrance.gouv.fr/affichTexte.do?cidTexte=JORFTEXT000031044385\&categorieLien=id (Letöltés: 2019. június 17.)

MEDDE (2013): Le programme national de prévention des déchets 2014-2020. https://www. ecologique-solidaire.gouv.fr/sites/default/files/Programme_national_prevention_dechets_2014-2020.pdf/ (Letöltés: 2017. szeptember 12.)

Szlávik J. (2013): Fenntartható gazdálkodás. Budapest: CompLex Kiadó

UBA (2017): Daten Zur Umwelt 2017. Umweltbundesamt: Dessau-Roßlau, Germany. 152 p. http://www.umweltbundesamt.de/sites/default/files/medien/376/publikationen/daten_zur_ umwelt_2017_indikatorenbericht.pdf (Letöltés: 2017. szeptember 12.) 
URL1: https:/ec.europa.eu/eurostat/tgm/table.do?tab=table\&init=1\&language=en\&pcode=t2020 rl100\&plugin=1 (Letöltés: 2018. június 16.)

URL2: https://ec.europa.eu/eurostat/tgm/refreshTableAction.do?tab=table\&plugin=1\&pcode=t2020 rl100\&language $=$ en (Letöltés: 2017. június 16.)

URL3: http://appsso.eurostat.ec.europa.eu/nui/show.do?dataset=nama_10_gdp\&lang=en (Letöltés: 2017. június 16.)

URL4: https://www.umweltbundesamt.de/indikator-gesamtrohstoffproduktivitaet\#textpart-1 (Letöltés: 2018. június 16.) 